OPEN ACCESS

Edited by:

Min-Te Chen,

National Taiwan Ocean University, Taiwan

Reviewed by:

Fengming Chang,

Institute of Oceanology (CAS), China

Jianguo Liu,

South China Sea Institute of Oceanology (CAS), China

*Correspondence: Zhengquan Yao yaozq@fio.org.cn

Xuefa Shi

xfshi@fio.org.cn

Specialty section:

This article was submitted to Quaternary Science, Geomorphology and Paleoenvironment, a section of the journal Frontiers in Earth Science

Received: 17 May 2021 Accepted: 24 June 2021

Published: 07 July 2021

Citation:

Wang A, Yao Z, Shi $X$, Wang K, Zou J, Liu Y, Wu Y and Gorbarenko SA (2021) Orbital and Millennial Variations in Sea Ice in the Southwestern Okhotsk Sea Since the Last Interglacial Period and

Their Implications.

Front. Earth Sci. 9:710797. doi: 10.3389/feart.2021.710797

\section{Orbital and Millennial Variations in Sea Ice in the Southwestern Okhotsk Sea Since the Last Interglacial Period and Their Implications}

\author{
Anqi Wang ${ }^{1}$, Zhengquan Yao ${ }^{1,2 *}$, Xuefa Shi ${ }^{1,2 *}$, Kunshan Wang ${ }^{1,2}$, Jianjun Zou ${ }^{1,2}$, \\ Yanguang $\mathrm{Liu}^{1,2}$, Yonghua $\mathrm{Wu}^{1,2}$ and Sergey A. Gorbarenko ${ }^{3}$ \\ ${ }^{1}$ Key Laboratory of Marine Geology and Metallogeny, First Institute of Oceanography, Ministry of Natural Resources, Qingdao, \\ China, ${ }^{2}$ Laboratory for Marine Geology, Pilot National Laboratory for Marine Science and Technology, Qingdao, China, ${ }^{3}$ V.I. \\ Il'ichev Pacific Oceanological Institute, Far East Branch of Russian Academy of Science, (FEB of RAS), Vladivostok, Russia
}

Sea ice in the Okhotsk Sea plays a significant role in global climate change. However, the history and mechanism of changes in sea ice spanning the last glacial cycle remain controversial. In this study, an $8.8 \mathrm{~m}$ core (LV55-40-1) was recovered from the southwestern Okhotsk Sea that contains a continuous sea ice record over the past $\sim 110 \mathrm{kyr}$. The sand fraction and dropstones were used as ice-rafted debris proxies to reconstruct the history of sea ice variations over the last $\sim 110 \mathrm{kyr}$ and to determine the underlying causes on orbital and millennial timescales. Sea ice expansions occurred during MIS 5b, MIS 4, mid-MIS 3, and early MIS 1, which were controlled mainly by decreased autumn insolation on an orbital timescale. Superimposed on the orbital-scale changes, millennial-scale variations in sea ice were also observed, with 19 expansion events that coincided with cold Dansgaard-Oeschger stadials. Millennial scale sea ice variations were most likely controlled by both the Arctic oscillation and the East Asian summer monsoon. During periods of negative Arctic oscillation patterns, decreased air temperatures over the Okhotsk Sea caused more active sea ice formation. Such conditions could have been reinforced, by a reduced influence of warm advection at the surface of the Okhotsk Sea caused by decreased discharge from the Amur River that resulted from a weakened East Asian summer monsoon during cold stadials.

Keywords: sea ice, ice-rafted debris, orbital scale, millennial scale, the Okhotsk Sea, the Amur River

\section{INTRODUCTION}

Sea ice is widespread in the subarctic North Pacific, and its expansion and retreat impact local and global climate changes by modulating the sea ice-induced albedo and energy budgets at both high and low latitudes (Turner et al., 2015; Serreze et al., 2016). Variations in sea ice influence the primary productivity in the Okhotsk Sea (Seki et al., 2004; Iwasaki et al., 2012; Jimenez-Espejo et al., 2018), as well as global ocean circulation and ventilation (Itaki, 2004). Consequently, sea ice variations on geologic timescales have played a significant role in paleoclimatic changes (Harada et al., 2012).

The Okhotsk Sea is located at the southernmost boundary of the region influenced by sea ice, and approximately two-thirds of the sea are covered by sea ice during the winter (Sakamoto et al., 2006). Therefore, sea ice coverage in the Okhotsk Sea is very sensitive to local and global changes in 
oceanography and climate (Nürnberg and Tiedemann, 2004; Seki et al., 2004; Sakamoto et al., 2005, Sakamoto et al., 2006; Nürnberg et al., 2011; Vasilenko et al., 2017; Vasilenko et al., 2019). The history of sea ice variations and their underlying causes have attracted attention from the paleoceanography research community (e.g., Nürnberg and Tiedemann, 2004; Sakamoto et al., 2006; Nürnberg et al., 2011; Vasilenko et al., 2017; Vasilenko et al., 2019; Lo et al., 2018). However, sea ice variations and their driving mechanisms over the last glacial cycle remain controversial. Some studies have suggested that the entire Okhotsk Sea has been influenced by seasonal/annual sea ice since the last interglacial period (Gorbarenko et al., 2003; Seki et al., 2004; Sakamoto et al., 2005; Sakamoto et al., 2006; Vasilenko et al., 2019; Gorbarenko et al., 2020), while other studies have demonstrated that perennial sea ice was present during severe cold stages, such as MIS 4, MIS 2 (Wang and Wang, 2008; Vasilenko et al., 2019), and at $\sim 30 \mathrm{ka}$ (Lo et al., 2018). Moreover, the mechanisms driving sea ice variations on orbital and millennial timescales are still debated. Previous studies have suggested that sea ice variations on orbital scales are controlled largely by glacial-interglacial cycles (Gorbarenko et al., 2002; Gorbarenko et al., 2003; Nürnberg and Tiedemann, 2004; Sakamoto et al., 2005). However, $\mathrm{C}_{25}$ highly branched isoprenoid $\left(\mathrm{IP}_{25}\right)$-derived sea ice records suggest that variations in sea ice in the central Okhotsk Sea were controlled by both insolation and atmospheric $\mathrm{CO}_{2}$ concentrations (Lo et al., 2018). In contrast, sea ice variations on millennial scales are more complex. Vasilenko et al. (2017) demonstrated that millennial-scale sea ice expansion was controlled by the velocity of geostrophic winds that dominated over the Okhotsk Sea, as the direction of ice drift coincided with the wind direction. The Arctic Oscillation (AO) is a dynamic atmospheric process in which the associated pressure changes over the Arctic influence atmospheric circulation over the Eurasian continent and adjacent areas (Thompson, 1998). It has been suggested that polar atmospheric circulation in the northern hemisphere is a key process that affects sea ice expansion on millennial scales (Sakamoto et al., 2006). Sakamoto et al. (2006) also inferred that discharge from the Amur River and polar atmospheric dynamics were potential factors that control sea ice expansion on millennial scales. Based on sea ice extents and inter-annual variations in Amur River discharge, Ogi et al. (2001) found a strong correlation between sea ice extent in the Okhotsk Sea and monsoon-induced fluvial discharge. However, there is no evidence suggesting that such a mechanism operates on geologic timescales. In addition, most of the sedimentary records related to sea ice changes during the last glacial cycle were from the central and eastern parts of the Okhotsk Sea, records from the southwestern Okhotsk Sea that are sensitive to fluvial effects are scarce. The southwestern Okhotsk Sea is subject to the influence of fluvial discharge via the East Sakhalin Current (Zhabin et al., 2010). Therefore, this is an ideal region for studying the history of sea ice cover and its potential connections with fluvial discharge. In this study, we analyzed an $8.8 \mathrm{~m}$ long core (LV55-40-1) collected from the southwestern Okhotsk Sea to determine the history of sea ice variations since $\sim 110 \mathrm{ka}$. Combined with previous results, we attempted to determine the dominant factors that control sea ice variations at orbital and -millennial timescales during the last glacial cycle.

\section{REGIONAL SETTING}

The Okhotsk Sea is the second largest marginal sea in the Pacific Ocean. It is surrounded by the Asian continent, Sakhalin Island, the Kamchatka Peninsula, the Kuril Islands and the island of Hokkaido. The Okhotsk Sea is connected to the North Pacific and the Japan Sea by the Straits of the Kuril Islands and by the Tatar and Soya straits, respectively (Figure 1).

Surface circulation in the Okhotsk Sea is characterized by a cyclonic gyre composed of the West Kamchatka Current (WKC), East Sakhalin Current (ESC), and the salty Soya Warm Current (SWC). The ESC flows along Sakhalin Island southward toward the Kuril Islands, and finally leaves the Okhotsk Sea through the Bussol Strait (Lapko and Radchenko, 2000). The water mass at $300-800 \mathrm{~m}$ depth in the Okhotsk Sea is called the Okhotsk Sea Intermediate Water (OSIW) and is characterized by low-density $\left(26.7-27 \sigma_{\theta}\right)$, low-salinity $(33.8 \%)$, and oxygen-rich water (Morley and Hays, 1983; Talley, 1993; Yang and Honjo, 1996). The OSIW has similar characteristics to the North Pacific Intermediate Water (NPIW) and is regarded as the present source of NPIW (Talley, 1991; Yasuda, 1997; Freeland et al., 1998; Martin and Kawase, 1998; Wong et al., 1998). Below the OSIW, ancient deep Pacific water masses enriched in $\mathrm{CO}_{2}$ flow into the Okhotsk Sea through the Krusenstherna Strait and flow out through the Bussol Strait (Nürnberg and Tiedemann, 2004).

The Amur River is the largest river in East Siberia and is adjacent to the northwestern continental shelf of the Okhotsk Sea. The drainage area of the Amur River is $\sim 1.85 \times 10^{6} \mathrm{~km}^{2}$ (Mclennan, 2013). The river delivers $\sim 14 \mathrm{t} \mathrm{km}^{-2}$ of sediment to the northern Okhotsk Sea annually, which is two to three times higher than that of other Siberian rivers, including those that drain into the Arctic Ocean (Anikiev et al., 2001). Freshwater input from the Amur River is approximately $310 \mathrm{~km}^{3}$ per year (Vörösmarty et al., 1996) and is mainly affected by the East Asian Summer Monsoon (EASM). Due to EASM precipitation and melting snow at high altitudes, the Amur River discharge is the highest during August-October, also producing the warmest water in the Okhotsk Sea $\left(\sim 20^{\circ} \mathrm{C}\right)$ during the same period (Ogi et al., 2001). The formation of a low-salinity layer in the Okhotsk Sea is mainly due to inflow from the Amur River (Freeland et al., 1998).

Sea ice in the Okhotsk Sea initially forms in November, starting in the northwestern part of the basin and repeatedly expanding southward (Sakamoto et al., 2005) due to transport by the northerly winds and the southward flow of the Okhotsk Sea (Ohshima et al., 2001; Wang et al., 2021). This creates a polynya along the coast and forms new sea ice (Sakamoto et al., 2005; Sakamoto et al., 2006). Sea ice in the Okhotsk Sea reaches its maximum extent during March, with a maximum thickness of $\sim 1 \mathrm{~m}$ (Rycroft, 1995). The sea ice disappears entirely in June, with ice-free conditions from July to October (Parkinson et al., 1987). The expansion and retreat of sea ice are influenced not only by ocean-atmosphere interactions, but also by the density of the 


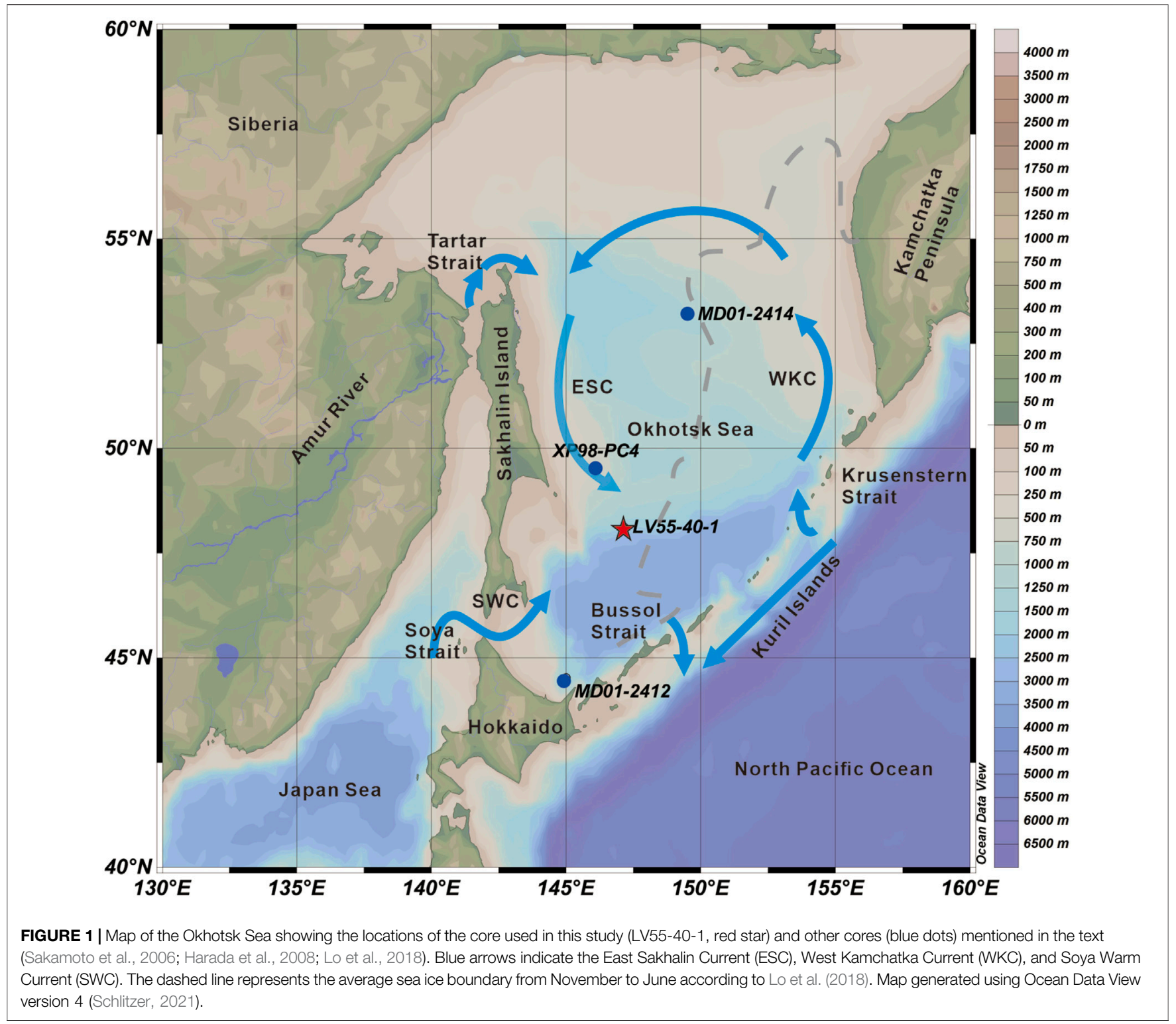

surface water that influences ocean circulation (Ohtani and Nagata, 1990). Intense sea ice formation causes brine rejection and forms Dense Shelf Water on the northern Okhotsk Sea shelves (Martin and Kawase, 1998; Gladyshev, 2003) and contributes to the formation and ventilation of the NPIW (Ohtani and Nagata, 1990; Talley, 1991; Wong et al., 1998).

\section{MATERIALS AND METHODS}

\section{Core Description}

Core LV55-40-1 $\left(48.12^{\circ} \mathrm{N}, 147.15^{\circ} \mathrm{E}\right)$ was recovered from the northern Kuril Basin in the southwestern Okhotsk Sea at a water depth of $1,730 \mathrm{~m}$ (Figure 1). The $8.8 \mathrm{~m}$ thick deposits were composed of homogeneous olive gray (5Y 4/2) silty clay with distinctive layers dominated by coarse-grained sand and gravel at $340-345 \mathrm{~cm}$ and $385-388 \mathrm{~cm}$ depths. These layers were also characterized by extremely high magnetic susceptibility, and abundant volcanic glass (Figure 2).

\section{Accelerator Mass Spectrometer ${ }^{14} \mathrm{C}$ Dating}

Mixed samples of the planktonic foraminifera Neogloboquadrina pachyderma (sinistral) and Globigerina bulloides larger than $145 \mu \mathrm{m}$ were collected from the core for accelerator mass spectrometer (AMS) ${ }^{14} \mathrm{C}$ dating (Table 1). The AMS ${ }^{14} \mathrm{C}$ analyses were performed by Beta Analytic Laboratory. Calibrated calendar ages were converted using CALIB 8.20 (Stuiver and Reimer, 1993) with the MARINE20 database (Heaton, 2020) and a calculated weighted mean $\triangle R=450 \pm 90$ a (Lo et al., 2018).

\section{X-Ray Fluorescence Scanning Analyses}

$\mathrm{X}$-ray fluorescence (XRF) scanning was performed at $0.5 \mathrm{~cm}$ intervals using an Itrax XRF core scanner with a $20 \mathrm{~s}$ count time, an X-ray voltage of $30 \mathrm{kV}$, and an X-ray current of 40-55 mA, which 


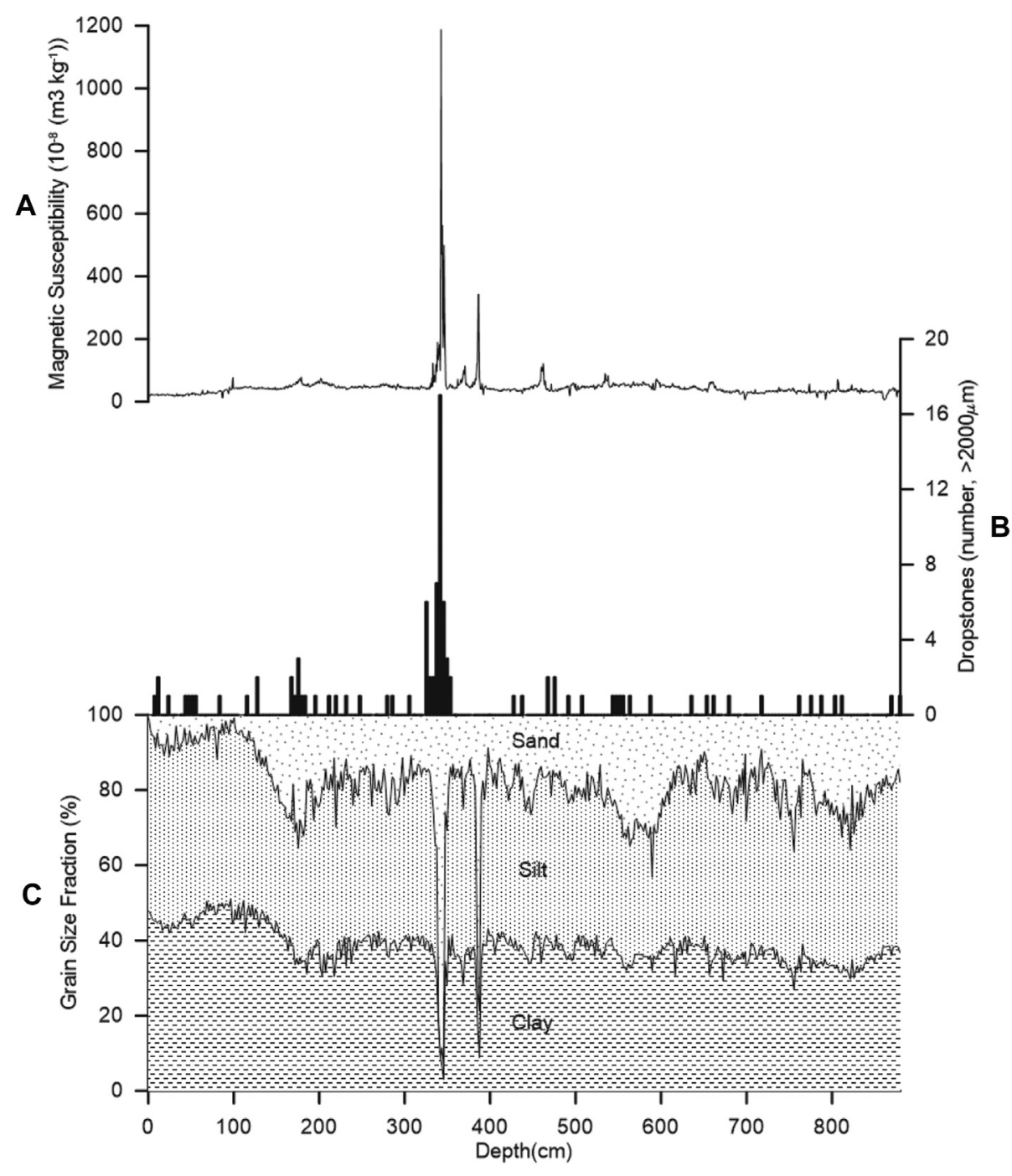

FIGURE 2 | Variations in (A) Magnetic Susceptibility, (B) Numbers of dropstones, and (C) Grain-size compositions with depth in core LV55-40-1.

TABLE 1 | $\mathrm{AMS}^{14} \mathrm{C}$ ages and calendar ages obtained from core LV55-40-1.

\begin{tabular}{|c|c|c|c|c|c|}
\hline Laboratory number & $\begin{array}{l}\text { Core depth } \\
\text { (cm) }\end{array}$ & $\begin{array}{c}\text { Conventional radiocarbon } \\
\text { age (a. BP) }\end{array}$ & \pm Error(a) & $\begin{array}{c}\text { Cal } B P \text { age } \\
\text { range }(95.4 \%)\end{array}$ & $\begin{array}{c}\text { Median cal } \\
\text { BP age }(95.4 \%)\end{array}$ \\
\hline Beta-577768 & 111.5 & 6,360 & 30 & $5,891-6,367$ & 6,127 \\
\hline Beta-576614 & 199.5 & 12,990 & 40 & $13,636-14,311$ & 13,957 \\
\hline Beta-577769 & 262.5 & 17,960 & 60 & $19,893-20,558$ & 20,243 \\
\hline Beta-577770 & 378.5 & 27,130 & 110 & $29,737-30,372$ & 30,042 \\
\hline
\end{tabular}

allowed for rapid, non-destructive, high-resolution elemental analyses of the sedimentary cores (Jansen et al., 1998).

\section{Biogenic Silica Analyses}

Biogenic silica (opal) analyses were performed on 440 samples using molybdate blue with modified pretreatments (Mortlock and Froelich, 1989). Opal was extracted using $40.0 \mathrm{ml}$ of $0.2 \mathrm{~mol} / \mathrm{L}$ $\mathrm{NaCO}_{3}$ solution at $85^{\circ} \mathrm{C}$ for $6 \mathrm{~h}$. During the analyses, $2 \mathrm{ml}$ of
$\mathrm{C}_{2} \mathrm{H}_{2} \mathrm{O}_{4}$ was added to avoid interference by $\mathrm{P}$ and As. The opal contents were quantified using a Mettler UV5 spectrophotometer. The relative standard deviation (RSD) was less than $3 \%$.

\section{Chlorin Analyses}

A total of 440 samples were analyzed to determine the chlorin concentrations with modified pretreatments (Harris and Maxwell, 1995). Briefly, $\sim 1 \mathrm{~g}$ of each sample was extracted 
using $20 \mathrm{ml}$ of $90 \%$ acetone and stored at $4^{\circ} \mathrm{C}$ for $24 \mathrm{~h}$ in the dark. The extracted liquor was centrifuged and filtered through GF/F membranes. The chlorin concentrations were determined using a TD-700 fluorometer. The RSD was less than $2 \%$.

\section{Ice-Rafted Debris Analyses}

In the Okhotsk Sea, coarse sediment fractions with grain sizes larger than $63 \mu \mathrm{m}$ in the Okhotsk Sea have been defined as icerafted debris (IRD) according to previous studies based on samples from sediment traps, surface sediments, and sediment cores from the region (Sakamoto et al., 2005). Laser diffraction and sieving of the IRD were performed, both of which were used to describe the grain size fractions in the core (Sakamoto et al., 2005, Sakamoto et al., 2006). Both of these methods were used in order to make the results more credible.

\section{Laser Diffraction Grain-Size Analysis}

Grain-size analyses were performed on 442 samples at $\sim 1-2 \mathrm{~cm}$ intervals to characterize the sediment texture using a Malvern Master size laser particle sizer (Malvern 3000) with a range of $\sim 0.02-2,000 \mu \mathrm{m}$. Carbonates, organic material, and diatoms were removed before analysis following the procedure introduced by Vasilenko et al. (2017). Briefly, $\sim 0.1$ g of sediment was pre-treated with excess $15 \% \mathrm{H}_{2} \mathrm{O}_{2}$ to remove organic matter, and with excess $10 \% \mathrm{HCl}$ to remove $\mathrm{CaCO}_{3}$. The liquid was centrifuged three times at $\mathrm{pH}=7$, then $20 \mathrm{ml}$ of $2 \mathrm{~mol} / \mathrm{L} \mathrm{Na}_{2} \mathrm{CO}_{3}$ was added and waterbathed at $85^{\circ} \mathrm{C}$ for $8 \mathrm{~h}$ to remove diatoms. Representative samples were observed under a microscope to ensure that the diatoms were completely removed. The accuracy of the measurements was $99 \%$ and the repeatability error was less than $0.1 \%$.

\section{Sieve Analysis}

Approximately 3-10 g of dry samples were weighed before sieving and washed with water passing through a $63 \mu \mathrm{m}$ mesh sieve. The residual samples on the sieve were dried at $60^{\circ} \mathrm{C}$ and passed through a 2,000 $\mu \mathrm{m}$ mesh sieve, and every fraction was weighed (Sakamoto et al., 2006; Nürnberg et al., 2011). The $>2,000 \mu \mathrm{m}$ grains (dropstones) were collected during core description, sampling and sieving, and were counted.

\section{Time-Series Analysis}

The IRD (vol\%) time series analysis was performed using the wavelet transform in Acycle (Li et al., 2019) and a 95\% confidence level was chosen. Cross-wavelet analysis visualizes the continuous variations in power and coherence in the time-frequency domain (Asahi et al., 2016). Prior to spectral analysis, all of the analyzed data were resampled at $0.2 \mathrm{kyr}$ for wavelet transform and crosswavelet analysis, which was the mean resolution of the sequence based on linear interpolation.

\section{RESULTS}

\section{Chronology}

The age model for core LV55-40-1 was constructed based on AMS ${ }^{14} \mathrm{C}$ dating of planktonic foraminifera and on correlation of the productivity proxies, such as $\mathrm{Ba} / \mathrm{Ti}$, chlorin and opal contents with marine and Greenland ice sheet oxygen isotopic records (Figure 3; Andersen et al., 2004; Lisiecki and Raymo, 2005). The $\mathrm{Ba} / \mathrm{Ti}$ ratio was assumed to indicate the relative contribution of biological and terrestrial inputs into the Okhotsk Sea, which covary with glacial-interglacial cycles with higher $\mathrm{Ba} / \mathrm{Ti}$ values during the interglacial periods (Figure 3C,F; Lo et al., 2018). Similarly, opal contents exhibited cyclic variations, with high abundances during interglacial periods and low abundances during glacial periods (Figure 3D). The correlation between opal contents and marine oxygen isotopes has been widely used to construct age models for deposits in the Okhotsk Sea (Narita et al., 2002; Sakamoto et al., 2006). In addition, magnetic susceptibility correlated with LR04 (Lisiecki and Raymo, 2005) and exhibited good correlations with $\log (\mathrm{Ba} / \mathrm{Ti})$ and opal contents (Figure 3C-E).

The chlorin content in the Okhotsk Sea increased during Dansgaarde-Oeschger interstadials (DOIs), and have also been used to construct high-resolution age models in the Okhotsk Sea (Gorbarenko et al., 2007; Gorbarenko et al., 2009; Gorbarenko et al., 2010; Gorbarenko et al., 2012; Vasilenko et al., 2017; Gorbarenko et al., 2020). Thus, the resolution of the age model was improved further by correlating the chlorin content to DOIs in Greenland ice cores. In core LV55-40-1, the peaks in chlorin content correlated well with long-lasting DOIs $8,12,14$, 19 , and 21 within established MISs (Figure 2F,G). The $8.8 \mathrm{~m}$ core thus revealed orbital and millennial variations with a basal age of 110 kyr (early MIS 5d; Figure 3).

\section{Variations in Ice-Rafted Debris in Core LV55-40-1}

The IRD (vol\%) content determined by laser diffraction was calculated as the volume percentage of the total terrigenous materials and excludes the influence of biological material. The IRD (wt\%) content determined by sieving includes both terrigenous grains and biogenic fractions. However, in the Okhotsk Sea, the biogenic fraction is insignificant (Sakamoto et al., 2006) and can be ignored in the sand fraction. Moreover, the variations in the IRD fraction between these two analytical methods were consistent in core LV55-40-1 (Figures 4C,D), which confirms the above inference, and indicates that both are suitable as proxies.

Variations in IRD (vol\%) ranged from 0.36 to $46.7 \%$ (Figures 4D, 5D). In general, IRD (vol\%) exhibited strong cyclic variations from $\sim 110$ to $\sim 10 \mathrm{ka}$ (Figure $4 \mathrm{D}$ ), mostly ranging from $\sim 5$ to $\sim 15 \%$. High-frequency fluctuations were observed at 105, 94, 87, $80,78,74,70,62,58,48,40,37,34,31,29,27,22,17$, and $12 \mathrm{ka}$ (Figure 5D,E). Two significant peaks in IRD (vol\%), with values of 46.7 and $39.3 \%$, corresponded to $\sim 31$ and $\sim 27 \mathrm{ka}$, respectively. The IRD (vol\%) was low during the Holocene, with a mean of $4.7 \%$. The variations in IRD (wt\%) ranged from $\sim 2$ to $\sim 52 \%$ throughout the core, and exhibited a similar pattern to those of the IRD (vol\%) (Figures 4D, 5D).

A total of 99 dropstones were collected from the core sequence (Figure 2B), with diameters ranging from 2 to $60 \mathrm{~mm}$. The presence of dropstones verifies the presence of sea ice, as ice rafting is the main transport method for grains larger than $2 \mathrm{~mm}$ 

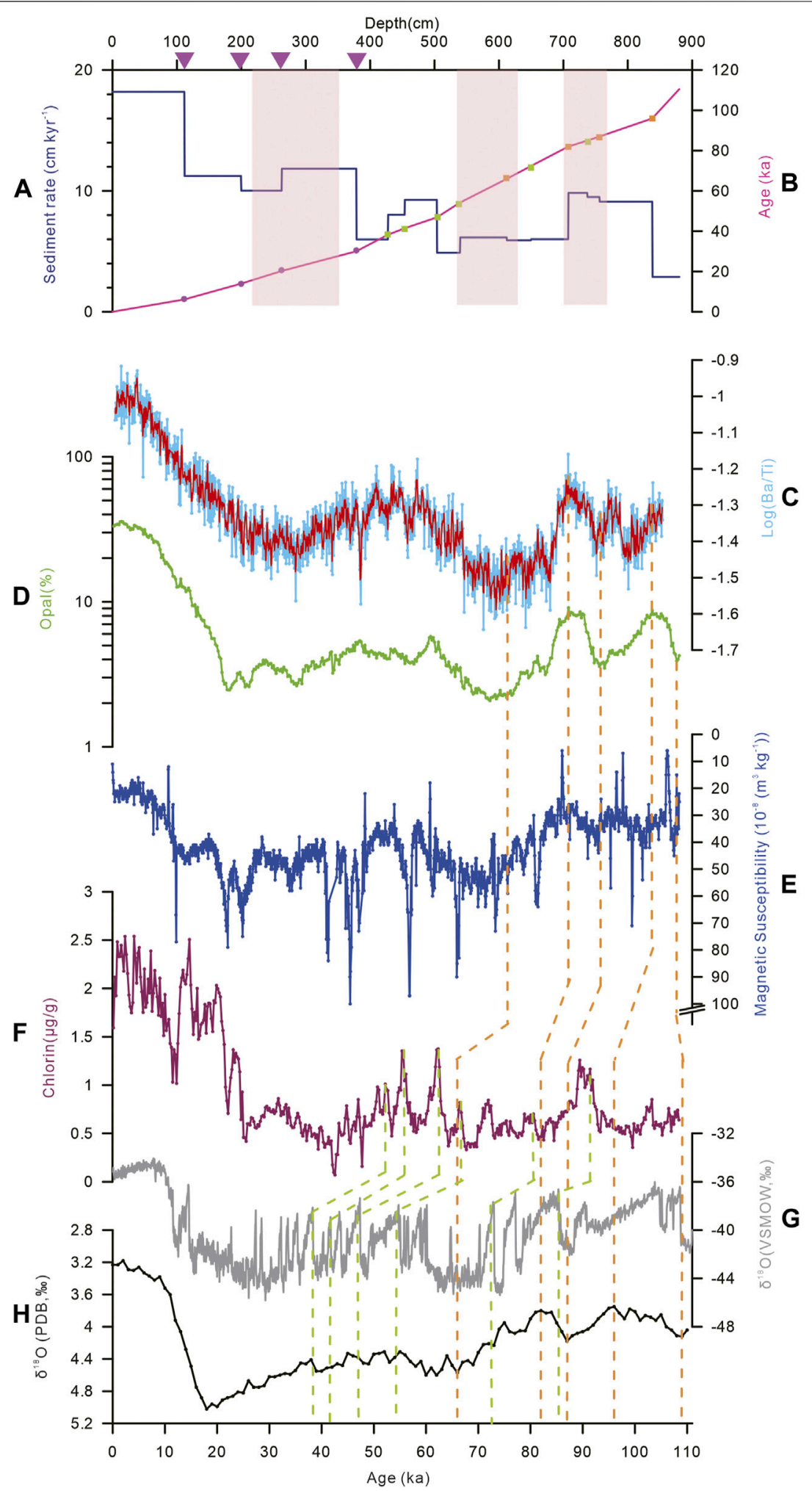

FIGURE 3 | Age model for core LV55-40-1. (A) Linear sedimentation rate, (B) Age-depth plot, (C) XRF-scanning log (Ba/Ti) ratio (blue line) with a 3-point running average (red line), (D) Opal content, (E) Magnetic susceptibility, (F) Chlorin concentration, (G) Oxygen isotopes from the NGRIP ice core (Andersen et al., 2004), and (H) LR04 $\delta^{18} \mathrm{O}$ stack (Lisiecki and Raymo, 2005). Purple triangles represent age model tie point using AMS ${ }^{14} \mathrm{C}$, orange and green dashed lines represent age control points obtained using correlations between the $\log (\mathrm{Ba} / \mathrm{Ti})$ ratio, opal content, magnetic susceptibility, and LRO4 $\delta^{18} \mathrm{O}$, and using correlations between chlorin concentrations and oxygen isotopes from the NGRIP ice core. Pink shadows represent glacial periods. 


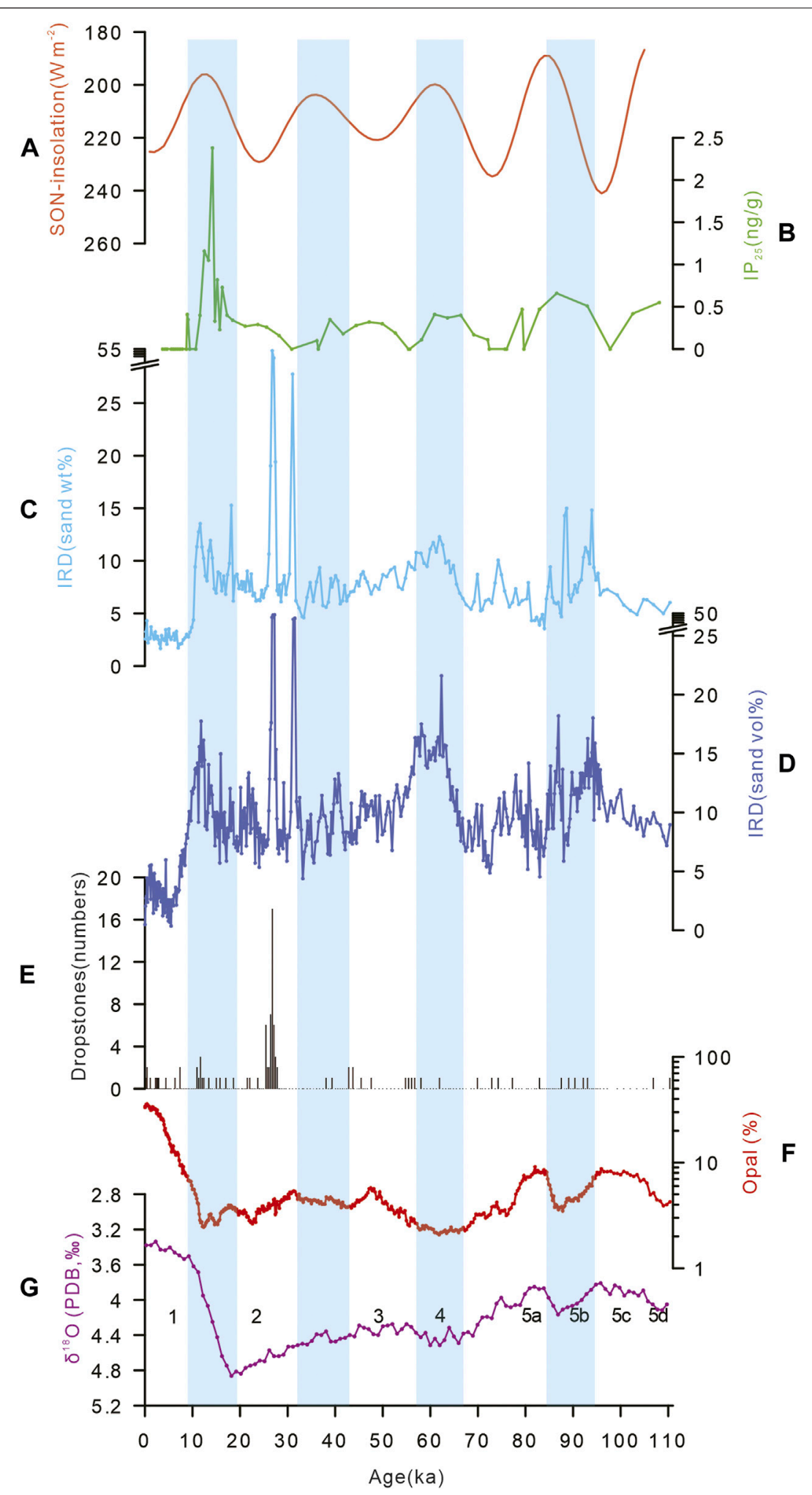

FIGURE 4 | Comparisons between variations in IRD proxies in core LV55-40-1 and other proxies. (A) SON-insolation (48 N; September, October, and November mean insolation), (B) IP 25 content in core MD01-2414 from the central Okhotsk Sea, a proxy of sea ice (Lo et al., 2018), (C) IRD (wt\%) in core LV55-40-1, (D) IRD (vol\%) in core LV55-40-1, (E) Number of dropstones in core LV55-40-1, (F) Opal content in core LV55-40-1, and (G) LR04 $\delta^{18}$ O stack (Lisiecki and Raymo, 2005). Blue shadows represent intervals of sea ice expansion. 


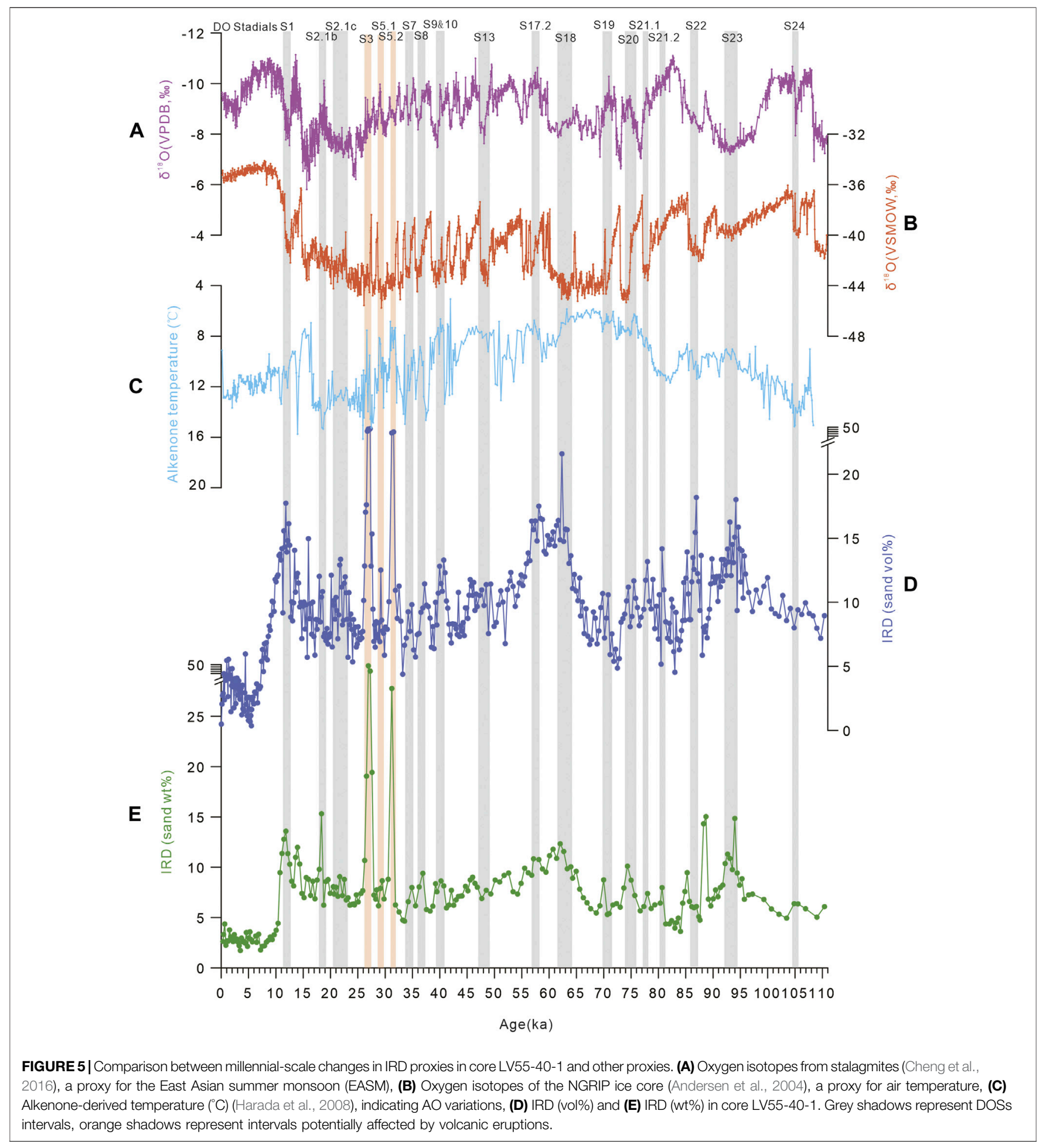

to hemipelagic regions, especially in areas influenced by seasonal sea ice (Sakamoto et al., 2006). Dropstones mostly occurred in intervals with high IRD contents, and the maximum number of dropstones (17) was observed at $\sim 27 \mathrm{ka}$, which may have also been influenced by volcanic eruption as suggested by the extremely high magnetic susceptibility (Figure 2A).

\section{DISCUSSION}

\section{Sea Ice Variations in the Okhotsk Sea on Orbital Timescale}

Ice rafting is the dominant method of transport for coarsegrained terrigenous material and dropstones to hemipelagic 
regions in the Okhotsk Sea (Sakamoto et al., 2006; Nürnberg et al., 2011). However, turbidity currents, gravity flows, and volcanic eruptions can also transport coarse materials into the sea (Nürnberg et al., 2011; Wang et al., 2017). Evidence of turbidity currents or gravity flows was not observed in core LV55-40-1, and has not been recorded in cores from nearby regions (Karp, 1996; Biebow, 1999). The extremely high magnetic susceptibility (Figure 2A) and volcanic glass observed at $\sim 31$ and $\sim 27 \mathrm{ka}$ implies that abundant volcanic materials were brought by either directly volcanic eruption or by sea ice, which was difficult to distinguish and may have affected the IRD content only during early MIS 2 (Figures 4D,G, 5D); however, this disturbance may be negligible because the abundant coarse volcanic material occurred as very thin layers in the core. The obvious effects of volcanic material on the IRD in the rest of the core could also be precluded due to the relatively low magnetic susceptibility values (Figure 2A).

The presence of IRD is generally the result of the expansion of sea ice under cold climatic conditions (Nürnberg and Tiedemann, 2004; Seki et al., 2004; Sakamoto et al., 2005, Sakamoto et al., 2006; Nürnberg et al., 2011). During cold stages, lower sea levels resulted in greater exposure of the surrounding continental shelf; thus, more terrigenous grains were captured and transported by sea ice to the ocean (Sakamoto et al., 2005). It has been suggested that perennial sea ice or ice-free conditions occur when IRD contents are 0\% or approximately 0\% (Seki et al., 2004; Sakamoto et al., 2005; Sakamoto et al., 2006). Seasonal sea ice is the only method that can transport dropstones to the ocean by ice rafting (Sakamoto et al., 2006), which is supported by the presence of dropstones during both warm and cold stages (Figures 2B, 4E-G). Even in the modern southwestern Okhotsk Sea, there is a small area of seasonal sea ice cover at the study site (Figures 4C,D). IRD was abundant throughout the sequence in core LV55-40-1, suggesting that seasonal sea ice was predominant in the southwestern Okhotsk Sea over the past $\sim 110 \mathrm{kyr}$. This is supported by analyses of IRD in cores MD01-2412 (Sakamoto et al., 2006) and XP98-PC4 (Sakamoto et al., 2005) from the southwestern Okhotsk Sea, which demonstrated that seasonal sea ice cover was present during the past $\sim 100 \mathrm{kyr}$. However, conditions were different in other regions. The diatom records from the central Okhotsk Sea suggested perennial sea ice conditions during MIS 2 and MIS 4 (Wang and Wang, 2008), whereas IRD records from the eastern Okhotsk Sea indicate a seasonal to perennial sea ice cover (Nürnberg et al., 2011). Other IRD records indicate that during MIS 2 perennial sea ice covered the Okhotsk Sea only near the northwestern and western coasts (Vasilenko et al., 2019). However, perennial sea ice conditions were not present at our study site, even during the Last Glacial Maximum (LGM). Instead, a seasonal sea ice cover was present (Figures 4C,D). This implies that sea ice variations in the Okhotsk Sea are spatially heterogeneous on geologic timescales (Gorbarenko et al., 2014; Bosin et al., 2015; Vasilenko et al., 2019).

Generally, sea ice variations in the Okhotsk Sea exhibit cyclic glacial-interglacial patterns on an orbital scale, with expanding sea ice extents during glacials and retreating sea ice extents during interglacials (Nürnberg and Tiedemann, 2004; Sakamoto et al., 2005; Nürnberg et al., 2011; Zou et al., 2015; Wang et al., 2017; Jimenez-Espejo et al., 2018). Variations in core LV55-40-1 do not strictly follow the glacial-interglacial cycles, and four obvious sea ice expansions were observed during MIS 5b, MIS 4, mid-MIS 3, and early MIS 1, as indicated by high IRD contents (Figure 4D). The reconstructed sea ice variations from this core are mostly consistent with the $\mathrm{IP}_{25}$ record from core MD01-2414 in the central Okhotsk Sea (Lo et al., 2018; Figures 4B,D).

Sea ice formation in the modern Okhotsk Sea mainly occurs during the winter (Parkinson et al., 1987; Rycroft, 1995). Previous studies have demonstrated that air temperature and sea-surface conditions during autumn play an important role in sea ice formation during the subsequent winter (Ogi et al., 2001; Ogi and Tachibana, 2006). Therefore, local autumn insolation may be related to sea ice formation during the winter. This inference is confirmed by a good correlation between the variations in sea ice derived from IRD and autumn insolation in the study area $\left(48^{\circ} \mathrm{N}\right.$; September, October, and November mean insolation, SON-insolation). Four sea ice expansions corresponded to either declining or minimum SONinsolation (Figures 4A,D). This suggests that seasonal sea ice variations on an orbital scale in the Okhotsk Sea were controlled by local autumn insolation, which exhibits a strong precession cycle. This inference is further supported by the wavelet transform analysis of IRD (Figure 6A) and a cross-wavelet analysis between IRD and SON-insolation (Figure 6B), which exhibited a strong 20-kyr cycle throughout the sequence (Figure 4D).

\section{Sea Ice Variations in the Okhotsk Sea on Millennial Timescale}

High-resolution variations in IRD revealed millennial-scale sea ice fluctuations over the past $\sim 110 \mathrm{ka}$, which are superimposed on the variability at the orbital scale. In total, 19 IRD peaks were observed throughout the sequence, which correspond with cold DansgaardeOeschger stadials (DOS) recorded by the Greenland ice sheet (Andersen et al., 2004; Figures 5B,D). Previous studies have reported that millennial-scale sea ice variations can be correlated with millennial climatic changes, such as DO cycles (Gorbarenko et al., 2003; Sakamoto et al., 2005; Sakamoto et al., 2006; Nürnberg et al., 2011; Vasilenko et al., 2017). A recent study suggested that the velocity of geostrophic winds over the Okhotsk Sea dominated sea ice drift, thereby causing the expansion of sea ice on millennial scales (Vasilenko et al., 2017). Mayewski et al. (1994) attributed rapid climatic changes to significant reorganization of atmospheric circulation, which stimulated changes in sea ice cover in the ocean. A study of the history of sea ice variations derived from IRD analyses also highlighted the importance of millennial-scale variations in polar atmospheric circulation for driving sea ice changes in the Okhotsk Sea (Sakamoto et al., 2005). Therefore, atmospheric circulation in the polar region and its correlation with pressure in the mid-latitudes might be related to sea ice changes in the Okhotsk Sea on a millennial scale (Sakamoto et al., 2005; Sakamoto et al., 2006; Harada et al., 2008).

The AO is a dynamic atmospheric process, and the associated pressure changes over the Arctic are opposite to those over the mid-latitude region in the Northern Hemisphere (Thompson, 1998). The AO exerts a strong influence on atmospheric circulation over the Eurasian continent and adjacent areas. Modern data suggests that sea ice cover in winter is strongly affected by the annual integrated AO in the Okhotsk Sea (Ogi and 

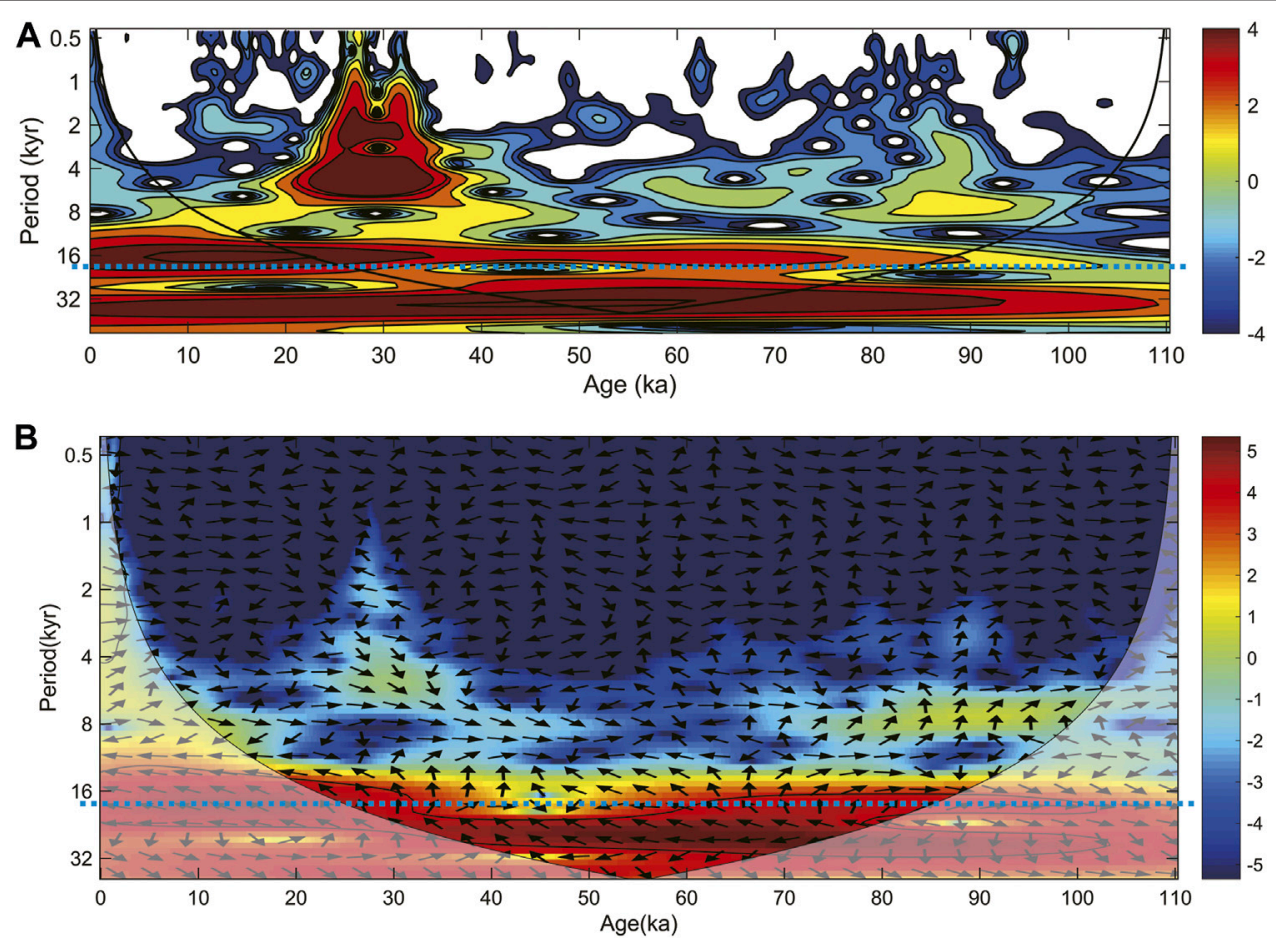

FIGURE 6 | (A) Continuous wavelet transform analysis of IRD (vol\%) in core LV55-40-1 and (B) Cross-wavelet analysis of IRD (vol\%) in core LV55-40-1 and SONinsolation. Blue dashed lines represent main orbital cycle of 20-kyr.

Tachibana, 2006). An IRD record from the central Okhotsk Sea also indicated that sea ice expansions in DOSs during the past $\sim 100 \mathrm{kyr}$ were the result of variations in polar atmospheric circulation in the Northern Hemisphere (Sakamoto et al., 2005). Therefore, the Arctic atmospheric processes must contribute to sea ice variations in the study area on a millennial scale. It has been suggested that the alkenone-derived ocean surface temperatures corresponded with AO on geologic timescales (Harada et al., 2008) and were coupled with temperature changes in the Arctic, with low temperatures indicating a negative $\mathrm{AO}$, and vice versa. Therefore, negative $\mathrm{AO}$ during stadials plays a dominant role in sea ice expansion in the Okhotsk Sea, as negative AO patterns are closely correlated with cold DOSs (Harada et al., 2008; Figures 5C,D). During these sea ice expansion intervals, cold air masses could have easily penetrated through the Arctic region during periods with negative AO pattern, lowering the air temperatures over the Okhotsk Sea and causing more active sea ice formation (Thompson and Wallace, 1998; Harada et al., 2008).

In addition to the effects of $\mathrm{AO}$, thermal anomalies at the ocean surface may have also influenced the sea ice formation in the Okhotsk Sea (Ogi et al., 2001; Sakamoto et al., 2005; Sakamoto et al., 2006; Harada et al., 2008). Such thermal anomalies are closely related to the discharge of warm freshwater (Ogi et al., 2001; Harada et al., 2008). In the modern Okhotsk Sea, the Amur River discharge brings warm water advection to the surface seawater, thereby reducing the sea ice formation during the subsequent winter (Ogi et al., 2001). On geologic timescales, the Amur River discharge is a potential factor that controlled sea ice variations during warm periods (Sakamoto et al., 2006). Core LV55-40-1 is located in an area east of the Sakhalin Islands, which is influenced by freshwater discharge from the Amur River that is transported by the ESC (Itoh and Ohshima, 2000; Sakamoto et al., 2005; Figure 1). Therefore, the discharge from the Amur River may have also contributed to sea ice variations during interglacial periods in the study area by modulating the sea-surface thermal conditions. As fluctuations in the Amur River discharge were controlled by the intensity of the EASM (Harada et al., 2008), the reconstructed variations in sea ice also corresponded well with the EASM variability on the millennial scale, with decreased sea ice formation during warm stages (Cheng et al., 2016; Figures 5A,D). During periods of enhanced EASM, increased monsoon precipitation would increase the discharge from the Amur River. The advection of this warm freshwater to the southwestern Okhotsk Sea caused thermal anomalies at the ocean surface (Ogi et al., 2001), thereby suppressing subsequent sea ice formation. In contrast, less warm freshwater input during cold stadials in the interglacials due to weak monsoonal conditions would allow more sea ice formation in the study area.

\section{CONCLUSION}

We reconstructed the history of sea ice variations in the southwestern Okhotsk Sea over the last $\sim 110 \mathrm{kyr}$ and investigated the factors controlling sea ice changes on orbital and -millennial timescales based on the IRD proxy. Seasonal sea 
ice was predominant in the southwestern Okhotsk Sea during the past $\sim 110 \mathrm{kyr}$. Sea ice expansion occurred during MIS 5b, MIS 4, mid-MIS 3, and early MIS 1, which corresponded to period of less SON-insolation. Combined with the strong 20-kyr cycles in the IRD proxy, we suggest that orbital-scale sea ice variations in the southwestern Okhotsk Sea were controlled primarily by local autumn insolation. The millennial-scale sea ice variations are related to DO cycles, with sea ice expansion corresponding to cold DOSs. We suggest that sea ice variations were impacted by both the AO and the EASM. During intervals of sea ice expansion, cold air masses could have easily penetrated through the Arctic region during periods of negative $\mathrm{AO}$ pattern, thereby lowering the air temperature in the Okhotsk Sea latitudes and causing more active sea ice formation. In addition, the high discharges of warm freshwater transported by the Amur River to the southwestern Okhotsk Sea during warm interstadials caused thermal anomalies at the ocean surface, thereby suppressing the subsequent sea ice formation. In contrast, lower warm freshwater input during cold stadials would allow more sea ice formation in the study area.

\section{DATA AVAILABILITY STATEMENT}

The original contributions presented in the study are included in the article/supplementary material, further inquiries can be directed to the corresponding authors.

\section{REFERENCES}

Andersen, K. K., Azuma, N., Barnola, J. M., Bigler, M., Biscaye, P., Caillon, N., et al. (2004). High-resolution Record of Northern Hemisphere Climate Extending into the Last Interglacial Period. Nature 431, 147-151. doi:10.1038/nature02805

Anikiev, V. V., Dudarev, O. V., Kolesov, G. M., Botsul, A. I., and Utkin, I. V. J. G. I. (2001). Factors of Mesoscale Variability in the Distribution of the Particulate Matter and Chemical Elements in the Amur River Estuary-Sea of Okhotsk Waters. Geochem. Int. 39, 64-87. doi:10.1134/S001670290905005X

Asahi, H., Kender, S., Ikehara, M., Sakamoto, T., Takahashi, K., Ravelo, A. C., et al. (2016). Orbital-scale Benthic Foraminiferal Oxygen Isotope Stratigraphy at the Northern Bering Sea Slope Site U1343 (IODP Expedition 323) and its Pleistocene Paleoceanographic Significance. Deep Sea Res. Part Topical Stud. Oceanography 125-126, 66-83. doi:10.1016/j.dsr2.2014.01.004

Biebow, N. (1999). KOMEX (Kurile Okhotsk Sea Marine Experiment). Cruise Reports: KOMEX I and II: RV Professor Gagarinsky Cruise 22, RV Akademik Lavrentyev Cruise 28. Geomar Reports.

Bosin, A., Gorbarenko, S., Xuefa, S., Liu, Y., and Zou, J. (2015). Regionalized Primary Paleoproduction Variability in the Sea of Okhotsk during Late Pleistocene and Holocene. J. Asian Earth Sci. 114, 534-540. doi:10.1016/ j.jseaes.2015.07.019

Cheng, H., Edwards, R. L., Sinha, A., Spötl, C., Yi, L., Chen, S., et al. (2016). The Asian Monsoon over the Past 640,000 Years and Ice Age Terminations. Nature 534, 640-646. doi:10.1038/nature18591

Freeland, H. J., Bychkov, A. S., Whitney, F., Taylor, C., Wong, C. S., and Yurasov, G. I. (1998). WOCE Section P1W in the Sea of Okhotsk: 1. Oceanographic Data Description. J. Geophys. Res. 103, 15613-15623. doi:10.1029/98jc00368

Gladyshev, S. (2003). Distribution, Formation, and Seasonal Variability of Okhotsk Sea Mode Water. J. Geophys. Res. 108, 3186. doi:10.1029/2001jc000877

Gorbarenko, S. A., Artemova, A. V., Goldberg, E. L., and Vasilenko, Y. P. (2014). The Response of the Okhotsk Sea Environment to the Orbital-Millennium Global Climate Changes during the Last Glacial Maximum, Deglaciation and Holocene. Glob. Planet. Change 116, 76-90. doi:10.1016/j.gloplacha.2014.02.002

\section{AUTHOR CONTRIBUTIONS}

AW, ZY, and XS designed the study, synthesized and analyzed the data, and wrote the manuscript with contributions from all authors. KW and YW analyzed the data related to sedimentology. YL, JZ, and SG helped collect the core. All authors contributed to the manuscript and approved its submission.

\section{FUNDING}

This work was jointly supported by the National Key Research and Development Program of China (No: 2016YFA0601903), NSFC-Shandong Joint Fund for Marine Science Research Centers (U1606401), the National Program on Global Change and Air-Sea Interaction (Grant No. GASI-GEOGE03), the Taishan Scholar Program of Shandong (XS), the Russian Science Foundation, Russia (Grant N_19-0500663A), and the Russian state budget 121021700342-9 of the Pacific Oceanological Institute, Far East Branch of the Russian Academy of Sciences.

\section{ACKNOWLEDGMENTS}

We thank the Editor and two reviewers for their valuable suggestions.

Gorbarenko, S. A., Goldberg, E. L. v., Kashgarian, M., Velivetskaya, T. y. A., Zakharkov, S. P., Pechnikov, V. S., et al. (2007). Millennium Scale Environment Changes of the Okhotsk Sea during Last $80 \mathrm{Kyr}$ and Their Phase Relationship with Global Climate Changes. J. Oceanogr. 63, 609-623. doi:10.1007/s10872007-0054-1

Gorbarenko, S. A., Harada, N., Malakhov, M. I., Vasilenko, Y. P., Bosin, A. A., and Gol'dberg, E. L. (2009). Millennial-scale Climatic and Environmental Oscillations in the Sea of Okhotsk in Response to Global Changes during the Last 190 Ka. Dokl. Earth Sc. 423, 1410-1413. doi:10.1134/ s1028334x08090183

Gorbarenko, S. A., Harada, N., Malakhov, M. I., Vasilenko, Y. P., Bosin, A. A., and Goldberg, E. L. (2010). Orbital and Millennial-Scale Environmental and Sedimentological Changes in the Okhotsk Sea during the Last 350kyr. Glob. Planet. Change 72, 79-85. doi:10.1016/j.gloplacha.2010.03.002

Gorbarenko, S. A., Harada, N., Malakhov, M. I., Velivetskaya, T. A., Vasilenko, Y. P., Bosin, A. A., et al. (2012). Responses of the Okhotsk Sea Environment and Sedimentology to Global Climate Changes at the Orbital and Millennial Scale during the Last 350kyr. Deep Sea Res. Part Topical Stud. Oceanography 61-64, 73-84. doi:10.1016/j.dsr2.2011.05.016

Gorbarenko, S. A., Khusid, T. A., Basov, I. A., Oba, T., Southon, J. R., and Koizumi, I. (2002). Glacial Holocene Environment of the southeastern Okhotsk Sea: Evidence from Geochemical and Palaeontological Data. Palaeogeogr. Palaeoclimatol. Palaeoecol. 177, 237-263. doi:10.1016/s0031-0182(01)00335-2 Gorbarenko, S. A., Yanchenko, E. A., Psheneva, O. g. Y., Harada, N., Bosin, A. A., Artemova, A. V., et al. (2020). Orbital and Millennial-Scale Environmental and Hydrological Changes of the central Okhotsk Sea over the Last 136 Kyr Inferred from Micropaleontological (Radiolarian and Benthic Foraminifera), Geochemical and Lithological Proxies and the Mechanisms Responsible for Them. Quat. Sci. Rev. 247, 106569. doi:10.1016/j.quascirev.2020.106569

Gorbarenko, S., Leskov, V. Y., Artemova, A., Tiedemann, R., Nicole, B., and Nuernberg, D. (2003). Ice Cover of the Okhotsk Sea during Last Glaciating and Holocene. Doklady Akademii Nauk 388, 678-682.

Harada, N., Sato, M., and Sakamoto, T. (2008). Freshwater Impacts Recorded in Tetraunsaturated Alkenones and Alkenone Sea Surface Temperatures from the 
Okhotsk Sea across Millennial-Scale Cycles. Paleoceanography 23, PA3201. doi:10.1029/2006pa001410

Harada, N., Takahashi, K., Timmermann, A., and Sakamoto, T. (2012). Climate Change Dynamics of Present and Past in the North Pacific and its Northern Marginal Seas. Deep Sea Res. Part Topical Stud. Oceanography 61-64, 1-3. doi:10.1016/j.dsr2.2012.01.001

Harris, P. G., and Maxwell, J. R. (1995). A Novel Method for the Rapid Determination of Chlorin Concentrations at High Stratigraphic Resolution in marine Sediments. Org. Geochem. 23, 853-856. doi:10.1016/0146-6380(95) 80007 -e

Heaton, T. (2020). Marine20 - the marine Radiocarbon Age Calibration Curve (055, 000 Cal BP). Radiocarbon, 1-42. doi:10.1017/rdc.2020.68

Itaki, T. (2004). Middle to Late Holocene Changes of the Okhotsk Sea Intermediate Water and Their Relation to Atmospheric Circulation. Geophys. Res. Lett. 31, L24309. doi:10.1029/2004gl021384

Iwasaki, S., Takahashi, K., Maesawa, T., Sakamoto, T., Sakai, S., and Iijima, K. (2012). Paleoceanography of the Last 500kyrs in the central Okhotsk Sea Based on Geochemistry. Deep Sea Res. Part Topical Stud. Oceanography 61-64, 50-62. doi:10.1016/j.dsr2.2011.03.003

Jansen, J. H. F., Van Der Gaast, S. J., Koster, B., and Vaars, A. J. (1998). CORTEX, a Shipboard XRF-Scanner for Element Analyses in Split Sediment Cores. Mar. Geology 151, 143-153. doi:10.1016/s0025-3227(98)00074-7

Jimenez-Espejo, F. J., García-Alix, A., Harada, N., Bahr, A., Sakai, S., Iijima, K., et al. (2018). Changes in detrital input, ventilation and productivity in the central Okhotsk Sea during the marine isotope stage 5 e, penultimate interglacial period. J. Asian Earth Sci. 156, 189-200. doi:10.1016/j.jseaes.2018.01.032

Karp, B. Y. (1996). RV Akademik M.A. Lavrentyev Cruise 27: Cruise Report GREGORY, German Russian Expedition for Geological/Geophysical Okhotsk Sea Research, Vladivostok - Pusan - Okhotsk Sea - Pusan - Vladivostok, September 7 - October 12, 1995. Geomar Reports.

Lapko, V. V., and Radchenko, V. I. (2000). Sea of Okhotsk. Mar. Pollut. Bull. 41, 179-187. doi:10.1016/s0025-326x(00)00109-0

Li, M., Hinnov, L., and Kump, L. (2019). Acycle: Time-Series Analysis Software for Paleoclimate Research and Education. Comput. Geosciences 127, 12-22. doi:10.1016/j.cageo.2019.02.011

Lisiecki, L. E., and Raymo, M. E. (2005). A Pliocene-Pleistocene Stack of 57 Globally Distributed Benthic $\delta 18 \mathrm{O}$ Records. Paleoceanography 20, PA1003. doi:10.1029/2004pa001071

Lo, L., Belt, S. T., Lattaud, J., Friedrich, T., Zeeden, C., Schouten, S., et al. (2018). Precession and Atmospheric $\mathrm{CO} 2$ Modulated Variability of Sea Ice in the central Okhotsk Sea since 130,000 Years Ago. Earth Planet. Sci. Lett. 488, 36-45. doi:10.1016/j.epsl.2018.02.005

Martin, S., and Kawase, M. (1998). The Southern Flux of Sea Ice in the Tatarskiy Strait, Japan Sea and the Generation of the Liman Current. J. Mar. Res. 56, 141-155. doi:10.1357/002224098321836145

Mayewski, P. A., Meeker, L. D., Whitlow, S., Twickler, M. S., Morrison, M. C., Bloomfield, P., et al. (1994). Changes in Atmospheric Circulation and Ocean Ice Cover over the North Atlantic During the Last 41,000 Years. Science 263, 1747-1751. doi:10.1126/science.263.5154.1747

Mclennan, S. M. (2013). Sediments and Soils: Chemistry and Abundances. Rock Physics \& Phase Relations. Washington: American Geophysical Union (AGU).

Morley, J. J., and Hays, J. D. (1983). Oceanographic Conditions Associated with High Abundances of the Radiolarian Cycladophora Davisiana. Earth Planet. Sci. Lett. 66, 63-72. doi:10.1016/0012-821x(83)90126-7

Mortlock, R. A., and Froelich, P. N. (1989). A Simple Method for the Rapid Determination of Biogenic Opal in Pelagic marine Sediments. Deep Sea Res. A. Oceanographic Res. Pap. 36, 1415-1426. doi:10.1016/0198-0149(89)90092-7

Narita, H., Sato, M., Tsunogai, S., Murayama, M., Ikehara, M., Nakatsuka, T., et al. (2002). Biogenic Opal Indicating Less Productive Northwestern North Pacific during the Glacial Ages. Geophys. Res. Lett. 29, 22-31. doi:10.1029/ 2001gl014320

Nürnberg, D., Dethleff, D., Tiedemann, R., Kaiser, A., and Gorbarenko, S. A. (2011). Okhotsk Sea Ice Coverage and Kamchatka Glaciation over the Last 350ka - Evidence from Ice-Rafted Debris and Planktonic $818 \mathrm{O}$. Palaeogeogr. Palaeoclimatol. Palaeoecol. 310, 191-205. doi:10.1016/j.palaeo.2011.07.011

Nürnberg, D., and Tiedemann, R. (2004). Environmental Change in the Sea of Okhotsk during the Last 1.1 Million Years. Paleoceanography 19, PA4011. doi:10.1029/2004pa001023
Ogi, M., and Tachibana, Y. (2006). Influence of the Annual Arctic Oscillation on the Negative Correlation between Okhotsk Sea Ice and Amur River Discharge. Geophys. Res. Lett. 33. doi:10.1029/2006gl025838

Ogi, M., Tachibana, Y., Nishio, F., and Danchenkov, M. A. (2001). Does the Fresh Water Supply from the Amur River Flowing into the Sea of Okhotsk Affect Sea Ice Formation? J. Meteorol. Soc. Jpn. 79, 123-129. doi:10.2151/jmsj.79.123

Ohshima, K. I., Mizuta, G., Itoh, M., Fukamachi, Y., Watanabe, T., Nabae, Y., et al. (2001). Winter Oceanographic Conditions in the Southwestern Part of the Okhotsk Sea and Their Relation to Sea Ice. J. Oceanogr. 57, 451-460. doi:10.1023/a:1021225303621

Ohtani, K., and Nagata, Y. (1990). The Role of the Okhotsk Sea on the Formation of the Oyashio Water. EOS Trans. Am. Geophys. Union 71 (28), 811.

Parkinson, C. L., Comiso, J. C., Zwally, H. J., Cavalieri, D. J., Gloersen, P., Campbell, W. J. J. S., et al. (1987). Arctic Sea Ice, 1973-1976: Satellite Passive-Microwave observations. Washington: NASA SP-459.

Rycroft, M. J. (1995). Arctic and Antarctic Sea Ice, 1978-1987: Satellite PassiveMicrowave Observations and Analysis. J. Atmos. Terrestrial Phys. 57, 445. doi:10.1016/0021-9169(95)90010-1

Sakamoto, T., Ikehara, M., Aoki, K., Iijima, K., Kimura, N., Nakatsuka, T., et al. (2005). Ice-rafted Debris (IRD)-based Sea-Ice Expansion Events during the Past 100kyrs in the Okhotsk Sea. Deep Sea Res. Part Topical Stud. Oceanography 52, 2275-2301. doi:10.1016/j.dsr2.2005.08.007

Sakamoto, T., Ikehara, M., Uchida, M., Aoki, K., Shibata, Y., Kanamatsu, T., et al. (2006). Millennial-scale Variations of Sea-Ice Expansion in the Southwestern Part of the Okhotsk Sea during the Past 120 Kyr: Age Model and Ice-Rafted Debris in IMAGES Core MD01-2412. Glob. Planet. Change 53, 58-77. doi:10.1016/j.gloplacha.2006.01.012

Schlitzer, R. (2021). Ocean Data View. Available at: odvawi.de

Seki, O., Ikehara, M., Kawamura, K., Nakatsuka, T., Ohnishi, K., Wakatsuchi, M., et al. (2004). Reconstruction of Paleoproductivity in the Sea of Okhotsk over the Last 30 Kyr. Paleoceanography 19, PA1016. doi:10.1029/2002pa000808

Serreze, M. C., Stroeve, J., Barrett, A. P., and Boisvert, L. N. (2016). Summer Atmospheric Circulation Anomalies over the Arctic Ocean and Their Influences on September Sea Ice Extent: A Cautionary Tale. J. Geophys. Res. Atmos. 121 (11), 11463-11485. doi:10.1002/2016jd025161

Stuiver, M., and Reimer, P. J. (1993). Extended 14C Data Base and Revised CALIB 3.0 14C Age Calibration Program. Radiocarbon 35, 215-230. doi:10.1017/ S0033822200013904

Talley, L. D. (1993). Distribution and Formation of North Pacific Intermediate Water. J. Phys. Oceanogr. 23, 517-537. doi:10.1175/1520-0485(1993)023<0517: Dafonp $>2.0 . \mathrm{Co} ; 2$

Talley, L. D. (1991). An Okhotsk Sea Water Anomaly: Implications for Ventilation in the North Pacific. Deep Sea Res. Part A. Oceanographic Res. Pap. 38, S171-S190. doi:10.1016/s0198-0149(12)80009-4

Thompson, D. W. J., and Wallace, J. M. (1998). The Arctic Oscillation Signature in the Wintertime Geopotential Height and Temperature fields. Geophys. Res. Lett. 25, 1297-1300. doi:10.1029/98GL00950

Turner, J., Hosking, J. S., Marshall, G. J., Phillips, T., and Bracegirdle, T. J. (2015). Antarctic Sea Ice Increase Consistent with Intrinsic Variability of the Amundsen Sea Low. Clim. Dyn. 46, 2391-2402. doi:10.1007/s00382-015-2708-9

Vasilenko, Y. P., Gorbarenko, S. A., Bosin, A. A., Artemova, A. V., Yanchenko, E. A., Shi, X.-F., et al. (2019). Orbital-scale Changes of Sea Ice Conditions of Sea of Okhotsk during the Last Glaciation and the Holocene (MIS 4-MIS 1). Palaeogeogr. Palaeoclimatol. Palaeoecol. 533, 109284. doi:10.1016/ j.palaeo.2019.109284

Vasilenko, Y. P., Gorbarenko, S. A., Bosin, A. A., Shi, X.-F., Chen, M.-T., Zou, J.-J., et al. (2017). Millennial Mode of Variability of Sea Ice Conditions in the Okhotsk Sea during the Last Glaciation (MIS 4-MIS 2). Quat. Int. 459, 187-200. doi:10.1016/j.quaint.2017.09.039

Vörösmarty, C., Fekete, B. M., and Tucker, B. A. (1996). Global River Discharge Database RivDis v1.0. Technical Documents in Hydrology, UNESCO. 1-1008.

Wang, K.-S., Shi, X., Zou, J., Kandasamy, S., Gong, X., Wu, Y., Yan, Q., et al. (2017). Sediment Provenance Variations in the Southern Okhotsk Sea over the Last 180 Ka: Evidence from Light and Heavy Minerals. Palaeogeogr. Palaeoclimatol. Palaeoecol. 479, 61-70. doi:10.1016/j.palaeo.2017.04.017

Wang, K., Shi, X., Zou, J., Liu, Y., Yao, Z., and Gorbarenko, S. A. (2021). Spatial Distribution and Provenance of Detrital Minerals of Surface Sediment in the Okhotsk Sea. Front. Earth Sci. 9, 636850. doi:10.3389/feart.2021.636850 
Wang, W., and Wang, L. (2008). Reconstruction of Oceanographic Changes Based on the Diatom Records of the Central Okhotsk Sea over the Last 500000 Years. Terr. Atoms. Ocean. Sci. 19, 403-411. doi:10.3319/tao.2008.19.4.403

Wong, C. S., Matear, R. J., Freeland, H. J., Whitney, F. A., and Bychkov, A. S. (1998). WOCE Line P1W in the Sea of Okhotsk: 2. CFCs and the Formation Rate of Intermediate Water. J. Geophys. Res. 103, 15625-15642. doi:10.1029/ 98jc01008

Yang, J., and Honjo, S. (1996). Modeling the Near-Freezing Dichothermal Layer in the Sea of Okhotsk and its Interannual Variations. J. Geophys. Res. 101, 16421-16433. doi:10.1029/96JC01091

Yasuda, I. (1997). The Origin of the North Pacific Intermediate Water. J. Geophys. Res. 102, 893-909. doi:10.1029/96jc02938

Zhabin, I. A., Abrosimova, A. A., Dubina, V. A., and Nekrasov, D. A. (2010). Influence of the Amur River Runoff on the Hydrological Conditions of the Amur Liman and Sakhalin Bay (Sea of Okhotsk) during the spring-summer Flood. Russ. Meteorol. Hydrol. 35, 295-300. doi:10.3103/s1068373910040084
Zou, J., Shi, X., Zhu, A., Chen, M.-T., Kao, S., Wu, Y., et al. (2015). Evidence of Sea Ice-Driven Terrigenous Detritus Accumulation and Deep Ventilation Changes in the Southern Okhotsk Sea during the Last 180ka. J. Asian Earth Sci. 114, 541-548. doi:10.1016/j.jseaes.2015.07.020

Conflict of Interest: The authors declare that the research was conducted in the absence of any commercial or financial relationships that could be construed as a potential conflict of interest.

Copyright (c) 2021 Wang, Yao, Shi, Wang, Zou, Liu, Wu and Gorbarenko. This is an open-access article distributed under the terms of the Creative Commons Attribution License (CC BY). The use, distribution or reproduction in other forums is permitted, provided the original author(s) and the copyright owner(s) are credited and that the original publication in this journal is cited, in accordance with accepted academic practice. No use, distribution or reproduction is permitted which does not comply with these terms. 